A list of Working Papers on the last pages

No. 294, 1991

THE NATURE AND IMPORTANCE OF ECONOMIC COMPETENCE

by

Bo Carlsson and Gunnar Eliasson 


\title{
The Nature and Importance of Economic Competence
}

by Bo Carlsson and Gunnar Eliasson

Case Western Reserve University, Cleveland, Ohio 44106, U.S.A., and Industrial Institute for Economic and Social Research (IUI), Stockholm, Sweden

\begin{abstract}
In this paper we define economic competence as the ability to identify, expand, and exploit the opportunity set. Economic competence constitutes the means through which technological possibilities are converted into economic activity. It consists of four types of capabilities: (1) Selective or strategic; (2) organizational or coordinating; (3) technical; and (4) learning ability.

The purpose of the paper is (1) to survey the study of economic competence as it appears in economic literature; (2) to give a meaningful and operational definition of economic competence as one of the factors contributing to macroeconomic growth; and (3) to suggest a methodology to generalize and link economic competence, as defined at the micro (firm, individual) level, to macroeconomic growth, through simulation on the micro-based macroeconomic Model of the Swedish Economic System (MOSES).
\end{abstract}



The Nature and Importance of Economic Competence

by Bo Carlsson and Gunnar Eliasson

\section{Introduction}

This paper takes on three tasks: (1) to survey the study of economic competence as it appears in economic literature; (2) to give a meaningful and operational definition of economic competence as one of the factors contributing to macroeconomic growth; and (3) to suggest a methodology - pursued in greater depth elsewhere - to generalize and link economic competence, as defined at the micro (firm, individual) level, to macroeconomic growth through simulation on the micro-based macroeconomic Model of the Swedish Economic System (MOSES). By introducing knowledge in the micro setting of firm organizational competence, we arrive at a very different interpretation measured at the macro industry level from that of standard neoclassical theory.

- This paper was written within the framework of the research project "Sweden's Technological System and Future Development Potential" financed by the National Board for Industrial and Technical Development (NUTEK) and the Swedish Council for Planning and Coordination of Research (FRN).

Previous versions of this paper were presented at the Eastern Economic Association meeting, Pittsburgh, PA, March 16, 1991, and at the European Association for Research in Industrial Economics, Ferrara, Italy, Sep. 3, 1991. The authors would like to thank Wesley M. Cohen, Paul Geroski, and Franco Malerba for helpful comments. 


\section{Economic Competence in Economic Literature}

The economic meaning of competence is the following: There is no productivity associated with physical factors of production (machines, labor hours, raw materials, etc.) unless they are coordinated by human competence for the purpose of earning a profit. Competence may be regarded as a form of capital which dominates other factors in creating a rent for the firm. Some of this competence is tacit and in many respects unique (Eliasson 1990a). This is true at all levels of the economy.

The idea that economic competence plays a fundamental role in the economy was recognized by economists from the very beginning. Already in 1768 the Swedish economist Johan Westerman investigated the sources of productivity differences between Swedish manufacturing on the one hand and British and Dutch manufacturing on the other. ${ }^{1}$ He discussed several circumstances and concluded that "[w] hat mattered was not the machines, but the human competence to organize machines and men, to know what products to produce and how to make customers happy with them." (Westerman 1768) This more than 200-year old analysis remains valid even today, although the insight has often been forgotten in economic analysis during the last century.

The classical economists were aware of the importance of economic competence. In his Principles of Political Economy (the first edition of which appeared in 1848), John Stuart Mill listed four primary factors causing "superior productiveness" of an economy: (1) natural advantages (fertility of soil, climate, mineral resources (Mill 1909, pp. 102-3); (2) labor energy;

1 The title of his little book is rather telling: Om de svenske näringarnes undervigt gentemot de utländske dymedelst en trögare arbetsdrift (On the Inferiority of Swedish Manufacturers Compared to Foreign Ones Due to a Slower Worker Organization). 
and (3) "the skill and knowledge of the laborers themselves, or of those who direct their labor" (p. 104). The invention and use of tools and machinery is one application of such knowledge (in this regard, Mill referred to work done earlier by Babbage On the Economy of Machinery and Manufactures (1835; first edition 1832); the implementation of improved techniques and processes is another. Mill treated as a separate factor (4) "the cooperation, or the combined action" of labor, of which he distinguished two kinds: "first, such cooperation as takes place when several persons help each other in the same employment" (i.e., economies of scale), and "secondly, such cooperation as takes place when several persons help each other in different employments" (p. 116). The latter aspect really refers to the division of labor; Mill elaborates on Adam Smith's (1776) exposition in this regard.

Writing a half century after Mill, Alfred Marshall (1890, Book IV, Chapter I) also distinguished between four main "agents of production": land, labor, capital, and organization; in connection with the latter Marshall emphasized the role of industrial training, division of labor, use of machinery, specialization, economies of scale, and business management.

Given this history of recognition on the part of leading economists of the importance of economic competence, it is surprising that neoclassical economic theory, based largely on Marshall's work, leaves no natural place for competence or knowledge. Perhaps it was Marshall's notion of the "representative firm", endowed with average characteristics, and forming the basis for microeconomic modeling henceforth, which led the profession astray. Thus, in static (neoclassical) theory, the firm is either a dimensionless (atomistic) entity without an economic role -- or a descriptive device, a production function which efficiently converts inputs into output, subject to a budget constraint. Firms which cannot be seen or which rest motionlessly in static equilibrium are of doubtful value in explaining important economic phenomena. Since it is 
assumed that the firm knows what to produce, how to produce it, what price to charge, what inputs to buy and what prices to pay, the firm as such is of no interest. The perfect knowledge with which the firm is assumed to be equipped enables it to optimize its behavior instantly and, even more critically, costlessly. The reason may be partly formalistic. Competence, as suggested by Westerman, Mill, and Marshall, creates a synergy or scale effect, a rent from combining inputs efficiently. Such scale effects are indeed the very rationale of the firm, as pointed out by Coase (see below). But scale effects lead uncomfortable lives in the modern, refined versions of neoclassical theory. Hence both firms and competence have in effect been assumed away.

Even though the firm as such was not of primary interest to Joseph Schumpeter, the role of the entrepreneur in economic development certainly was. The central feature of entrepreneurial activity analyzed by Schumpeter was innovation: identification of new business opportunities, bringing together the resources necessary to exploit the opportunities, and introducing new products, processes, markets, sources of supply and organization. He distinguished between the role of the entrepreneur (creator of new activities) and that of the manager (coordinator of ongoing activites). Schumpeter's (1912) theory is more about the creating and setting up of new firms (entry) than it is about operating a firm in a market environment.

But as is well known, the works of Schumpeter were largely ignored in the economics profession for several decades. The same fate befell Richard Coase whose seminal work on the theory of the firm (1937) was not widely acknowledged until the 1970s. Coase's contribution was the idea that firms exist because it is costly to use the price system; the ability to coordinate economic activity is the rationale for the very existence of firms. This notion was picked up by Alchian and Demsetz (1972), who identified "team production" as an essential feature in the analysis of firms, and by Oliver Williamson (1975) in his analysis of "hierarchies versus markets". 
Meanwhile, Herbert Simon's work in the 1950s (e.g., 1955; 1957) on "bounded rationality" and the administrative structure of firms spawned the branch of literature on the theory of the firm referred to as the Behavioral School, recognizing the limitations on the span of control in efficiently running the firm. Thus, Simon questioned the very foundation of neoclassical theory: the inclination and ability of firms to maximize profit. ${ }^{2}$

The term "distinctive competence" was first used by Selznick (1957) to describe the character of an organization. It refers to those things that an organization does especially well in comparison with its competitors.

Even though it was not its primary thrust, the pathbreaking study by Edith Penrose (1959) identified many of the basic components of firms' capabilities. In discussing the limits to the growth of firms, she showed "not only that the resources with which a particular firm is accustomed to working will shape the productive services its management is capable of rendering ... but also that the experience of management will affect the productive services that all its other resources are capable of rendering" (p. 5) -- an idea later elaborated on by Romer (1986).

Penrose viewed the firm as a collection of productive resources (physical or tangible resources - plant, equipment, raw materials, etc. - and human resources - unskilled and skilled labor, clerical, administrative, financial, legal, technical and managerial staff) but also as an administrative organization. The administrative structure of the firm is created by the men who run it; the structure may have developed rather haphazardly in response to immediate needs, or it may have been shaped largely by conscious attempts to achieve a "rational" organization; it can,

2 This had already been questioned by the behaviorist side in the so-called marginalistbehaviorist debate in the 1940s, in which the marginalist side argued in effect that all that was needed for prediction of outcomes was profit maximization on the part of firms. For a discussion of the debate and its importance for economic theory, see Machlup (1967). 
in principle, always be adapted to the requirements of the firm - expanded, modified, and elaborated as the firm grows and changes (pp. 31-2).

The firm faces a "productive opportunity" comprising all of the productive possibilities that its "entrepreneurs" see and can take advantage of. The growth of the firm is essentially limited by its productive opportunities which, in turn, are restricted by the firm's ability to see opportunites for expansion, its willingness to act upon them (by expending effort and committing resources to the investigation of whether there are further opportunites of which it is not yet aware), and ability to respond to them - what Penrose called "enterprise".

Like Schumpeter had done earlier, Penrose also distinguished between managerial and entrepreneurial competence, the latter being associated with "enterprise" (search for opportunites requiring entrepreneurial intuition, imagination, judgement, ambition, and fund-raising ability):

[Businessmen] may have a high degree of managerial skill and imagination; they may be hard and efficient workers, but the ambition that would drive other men in the same circumstances to expand their operations in an unending search for more profit, and perhaps greater prestige, may be lacking ... Entrepreneurial preferences of this sort provide exactly the same kind of restriction on a firm's growth as does entrepreneurial inability to perceive or to act upon opportunites for profitable growth ... (p. 35).

Penrose also articulated the idea that the organization working as a team is greater than the sum of its constituent parts:

Businessmen commonly refer to the managerial group as a "team", and the use of this word implies that management in some sense works as a unit. An administrative group is something more than a collection of individuals; it is a collection of individuals who have had 
experience in working together, for only in this way can "teamwork" be developed. Existing managerial personnel provide services that cannot be provided by personnel newly hired from outside the firm, not only because they make up the administrative organization which cannot be expanded except by their own actions, but also because the experience they gain from working within the firm and with each other enables them to provide services that are uniquely valuable for the operations of the particular group with which they are associated (p. 46).

The notion that teamwork creates organization-specific knowledge which can neither be obtained from the outside nor transferred to another organization is closely related to Polanyi's work on personal knowledge with particular emphasis on its tacit component (1958), further elaborated in The Tacit Dimension (1966). Although Polanyi and Penrose were working simultaneously, their work appears to have been independent of each other.

The publication of Alfred Chandler's Strategy and Structure in 1962 spawned a whole new branch of economic and management literature on corporate strategy. Chandler focused on the relationships among the competence of the firm in various functional areas, corporate strategy, and administrative structure of the organization. These concepts have been further analyzed in his subsequent studies, particularly The Visible Hand (1977) and Scale and Scope (1990).

It was not until the 1870 s, with the completion of the modern transportation and communication network - the railroad, telegraph, steamship, and cable - and of the organizational and technological innovations essential to operate them as integrated systems, that materials could flow into a factory or processing plant and finished goods move out at 
a rate of speed and volume and with the precise timing required to achieve substantial economies of throughput ... Thus the revolution in transportation and communication created opportunities that led to a revolution in both production and distribution (Chandler 1990, p. 26).

Chandler pointed out that the potential economies of scale and scope, created by this "revolution," reflect the physical characteristics of production facilities. But physical production facilities alone are not sufficient: "The actual economies of scale or of scope, as determined by throughput, are organizational. Such economies depend on knowledge, skill, experience, and teamwork - on the organized human capabilities essential to exploit the potential of technological processes". (Chandler 1990, p. 24; emphasis added).

Chandler's latest study (1990) also links corporate (i.e., microeconomic) capabilites to macroeconomic performance. He does so by describing and anlyzing the "organizational capabilities" of the 200 largest corporations in the United States in comparison with the 200 largest in Germany and Great Britain and demonstrating their importance in explaining the differences in economic performance of these three nations over the course of the first half of the twentieth century. Chandler attributes a great deal of the superior performance of American industry compared to that in Germany and Britain to the earlier "coming of age" of the large business corporations in the United States, their ability to organize themselves in such a way as to be able to take advantage of the potential economies of scale and scope created by a large and rapidly growing domestic market, well-functioning, centralized and institutionalized financial 
markets, and a number of major technical innovations (esp. mass production and distribution of electric power)..$^{3}$

These organizational capabilites were the collective physical facilities and human skills as they were organized within the enterprise. They included the physical facilities in each of the many operating units - the factories, offices, laboratories - and the skills of the employees working in such units.

But only if these facilities and skills were carefully coordinated and integrated could the enterprise achieve the economies of scale and scope that were needed to compete in national and international markets and to continue to grow. Thus even more important to the maintenance of market share than the capabilities of the lower-level managers in charge of the operating units were those of the middle managers responsible for the performance of the lower-level executives. These middle managers not only had to develop and apply functional-specific and product-specific managerial skills, but they also had to train and motivate lower-level managers and to coordinate, integrate, and evaluate their work. And most critical to the long-term health and growth of the industrial enterprise were the abilities of the senior executives - the top operating managers and those in the corporate office - who recruited and motivated the middle managers, defined and allocated their responsibilities, and monitored and coordinated their activites, and who, in addition, planned and allocated the resources for the enterprise as a whole.

3 A similar conclusion was reached in Eliasson et al. (1984 and 1985): The large Swedish corporations have achieved large economies of scale through superior organization and internationalization. 
Such organizational capabilities, of course, had to be created, and once established, they had to be maintained. Their maintenance was as great a challenge as their creation, for facilities depreciate and skills atrophy. Moreover, changing technologies and markets constantly make both existing facilities and skills obsolete. One of the most critical tasks of top management has always been to maintain these capabilities and to integrate these facilities and skills into a unified organization - so that the whole becomes more than the sum of its parts. (Chandler 1990, p. 594.)

Eliasson (1980) carried out a similar analysis in which the performance characteristics of firms, notably large firms, were placed in the micro-macro economic setting of the Swedish micro-based growth model. His conclusion was that organizational change within firms and in markets between firms was the driving force behind macroeconomic growth. In a historic perspective most firms did not survive, but those who did possessed the competence to constantly and innovatively reorganize themselves, such that practically nothing of past interior firm structures remained after a few decades.

Teece (1988) has defined a firm's competence as a set of differentiated technological skills, complementary assets, and organizational routines and capacities that provide the basis for a firm's competitiveness in a particular business; it is essentially a measure of the firm's ability to solve both technical and organizational problems. More recently, Dosi, Teece and Winter (1990) have introduced the concept of "corporate coherence" by which they mean that a firm's lines of business are related in the sense that they have certain technological and market characteristics in common. At the same time, they distinguish coherence from specialization, the latter being regarded as a special case when coherence is confined to a single product line. A similar line of 
argument is pursued by Prahalad and Hamel in a recent article (1990) in which they elaborate on the "core competence of the corporation". They give the following examples of core competencies: miniaturization as a focus of business strategy at Sony; Honda's emphasis on engines and power trains; and Canon's competence in optics, imaging, and microprocessor controls - and their combination - which have enabled the company to obtain a strong position in markets as seemingly diverse as copiers, laser printers, cameras, and image scanners (ibid., pp. 82-3).

\section{The Role of Economic Competence}

As pointed out in Eliasson (1989b, 1990a), competence is a very general concept. To relate it to firm objectives such as profits, it has to be given operational content. This is where the scientific challenge enters. Operational definitions easily become too narrow and trivial. When the tests are properly set up, such variables are easily rejected, even though they may be part of the complex set of factors that account for superior performance. This is the way it has to be. Critical business competence has a tacit, incommunicable dimension, even for the researchers. Were it not so, the unique competence would long ago have been widely diffused. Research on business competence thus borders on the un-researchable.

Nevertheless, we now proceed to defining economic competence. Each economic unit faces an opportunity set comprising all possible productive possibilities, including possibilities to expand. Economic competence is the ability to identify, expand, and exploit the opportunity set. Invention and innovation lead to economic change only to the extent that agents within the 
system are successful in taking advantage of the opportunities to which they give rise. Although economic competence may refer to organizations at any level of the economy, it is useful to distinguish analytically between competence pertaining to the economy as a whole, henceforth referred to as economic competence, and that pertaining to microeconomic units (primarily firms), henceforth referred to as firm (or business) competence. Other units, e.g. government bodies, private and public institutions, also possess economic capabilities. The economic competence of a nation constitutes the aggregate of the capabilities of all economic units within the economy, plus the additional capability derived from their effective coordination (systems effect).

In neoclassical theory, economic agents are generally assumed to have perfect knowledge so as to be able to optimize their behavior. As pointed out by Pelikan (1988 and 1989), once it is recognized not only that economic agents (especially firms) do not have perfect knowledge but also that they operate with different knowledge bases and under different assumptions concerning technology, markets; etc., an entirely different theoretical framework is called for, namely evolutionary theory. Economic competence is a scarce resource which is itself in need of efficient allocation. (Pelikan, 1988, pp. 383-5). It is therefore fundamental to the nature and functioning of the economic system and cannot be taken for granted. Economic agents differ in the information they have and in how they use it.

At the macro level there is a systems effect: the aggregate result of the capabilities of various units within the system can be large or small depending on the degree of economic competence used in combining and coordinating the capabilities of individual units. This coordination is a function of the organizations and institutional rules (together referred to as "institutions") guiding and providing incentives for economic activity within the system. 
Pelikan (1988) argues that the nature and allocation of economic competence in the capitalist system is inherently superior to that in centrally planned systems. It is interesting in this connection to consider the Japanese experience. It is possible to interpret some of the reasons advanced by various authors for the superior performance of the Japanese economy in recent decades as reflecting a high degree of economic competence in the Japanese economy, and a capacity of the economic system to put it to efficient use and to constantly upgrade it. Stated like that, however, the proposition is tautological. Some kind of positive competence must always explain superior performance that cannot be explained by visible factor inputs (Eliasson 1990b).

In order to formulate a testable hypothesis (capable of being refuted), we have to give empirical content to this competence, such as the following: One could argue that the ability on the part of agents within the economy (including leading business firms and government bodies such as the Ministry of International Trade and Industry (MITI)) to achieve superior overview, to envision and formulate goals, to design strategies to reach those goals, to motivate and educate people has contributed significantly to Japanese economic performance. This is basically a sophisticated version of the old central planning argument based on central overview. In a static equilibrium framework, such a central overview can be shown to be possible to achieve -- that is the implication of Pelikan's argument. But in a dynamic framework in which bounded rationality and tacit knowledge play an important role, no exogenous equilibrium can be made visible through improved overview. In such a framework, the ability to choose the right orientation and content of business activity, and the ability to learn to do it better, is what matters. Top level strategic competence becomes an important aspect of economic competence. Such capacities can, at least in principle, be subjected to empirical verification (Eliasson 1990a, b). 


\section{The Elements of Business Competence}

It is useful to distinguish between four types of capabilities which together determine the firm's economic or business competence (ability to generate and take advantage of business opportunities):

(1) selective (strategic) capability: the ability to make innovative choices of markets, products, technologies, and organizational structure; to engage in entrepreneurial activity; and especially to select key personnel and acquire key resources, including new competence;

(2) organizational (integrative, coordinating) capability;

(3) technical (functional) ability relating to the various functions within the firm, such as production, marketing, engineering, research and development, as well as product-specific capabilities; and

(4) leaming ability.

These capabilities may be thought of as a hierarchy of competence, illustrated in Figure 1. The operational level at the bottom of the pyramid represents the various functions; this is where physical work is done. The functions need to be coordinated and integrated; this is the task of middle management. The top of the pyramid represents the control exercised by top management on all the activities of the firm. This is manifested primarily in the organization, allocation, and upgrading of human competence (learning) in the organization. Thus, the choices made and the selection mechanisms used serve the dual function of exercising control while at the same time facilitating organizational learning. A balance needs to be struck between these two; rigid control 
prevents organizational learning and ties down the innovative, selective activities, while too much adaptability causes loss of control.

The neoclassical model treats knowledge and competence as fully tradable information. There is no need for firms (hierarchies) and therefore no room for differences in firm behavior. The various functions are coordinated by the market. But in the presence of bounded rationality and tacit knowledge, two things happen. First, trading of information is no longer sufficient; much of the required knowledge is not tradable. Secondly, organizing economic activities is not simply an act of coordination but rather the art of combining functional activities and integrating them with information activities to achieve synergistic effects, or scale effects, at the level of the entire firm. When all knowledge can be treated as tradable information, as in standard economic information theory, no synergy effects arise. There are no new organizing choices made; selection does not occur.

When knowledge is tacit, it can only be diffused through selection, i.e. through the movement of people or teams of people. But the diffusion of knowledge also requires a certain amount of receiver competence (Eliasson 1990a, b). Firms provide the structure for such selective and receptive activities. Firm management is needed to make choices about what and how to produce, where to sell, etc., to organize and coordinate activities, and to learn.

\subsection{Selective (Strategic) Capability}

Choices have to be made at all levels of the firm. This is done through formulation of overall business strategy (what to produce and where to sell, what technology to use, etc.), through continual development of an appropriate organizational structure, and through selection of key personnel (including the top management) and design of information, training, and incentive 
systems. The selection of human talent at the top of the organization controls all other downstream choices, including the choice of organization and mechanisms for allocating resources and filtering people to the top; it defines the "corporate culture."

Innovative or creative ability is a special form of selection: the ability to organize the firm so as to generate and take advantage of new business opportunities. This skill reflects what Schumpeter (1934) referred to as enterpreneurship: the ability to create new combinations in the form of new products and processes, new ways to organize economic activity, new markets and sources of supply. Later he referred to such new combinations as innovations. Innovations may be the result of new ideas (inventions) made within the organization. But they may also be the result of the firm's ability quickly to identify new business opportunites resulting from ideas coming from outside the organization. The creativity of the firm is its ability to generate innovations, thereby expanding the opportunity set, not just react to exogenous changes, and its willingness to make educated guesses and take appropriate risks.

Thus, the innovative capability of the firm determines how the firm interacts with the opportunity set. Firms differ in their ability to perceive opportunities, in their willingness to take risks, and in their ability to take advantage of opportunities. They also differ in their ability to expand the opportunity set (for themselves as well as others) through their own inventions and innovations.

Selective capability also involves the ability to estimate correctly the limits of the competence of one's own firm and that of other firms, and the ability to maintain flexibility; this is reflected throughout the firm and its activities, particularly in the choice of strategy and organizational design. 
By making a series of choices in a particular direction, a firm can change or upgrade its competence and its focus. By successfully focusing its efforts, a firm can develop a distinctive competence profile. Thus, selective or strategic competence may be viewed as the particular subsets of capabilities (distinctive competencies) in each of the categories of firm capabilities (organizational, functional, and learning) which are deemed to best support the particular strategy chosen by the firm.

This is not to suggest, however, that changing the core competence of an organization is an easy matter. The literature in both corporate strategy and industrial development indicates that current options are often severely limited by "the grip of the past," regardless of whether such path dependence is a result of historical accidents or conscious decisions (see David 1985; Arthur 1989).

\subsection{Organizational Capabilities}

Coordination is the capacity of the firm to integrate and organize its activities so as to achieve synergy effects at the firm level. Coordination (without synergy effects) is the traditional information activity in economic theory. It occurs in markets (the invisible hand of Adam Smith, 1776) or in hierarchies (the visible hand of Alfred Chandler 1977). As described by Chandler (1990, pp. 9-10) and Eliasson (1976), the organizational (coordinating) ability of a hierarchy refers to the essential functions of middle management. Specifically, it refers to the ability to put together the various functional abilities of the firm such that it beats the market in minimizing coordination costs. Since the market achieves coordination through a decentralized organization, the visible hand must achieve synergies from coordination, making total production greater than the sum of its constituent parts. This requires competence that defines the managed (collective) 
activity as a firm, or as a "competent team" or a hierarchy of competent teams (Eliasson 1989b, 1990a) capable of earning a rent through coordination superior to that of the market.

These middle management functions include coordination and integration of functional activities (production, marketing, $R \& D$, finance, etc.) in order to achieve potential economies of scale and scope (synergistic effects). This integrative ability is largely tacit. It is imbedded in persons and organizations and cannot be easily articulated or transferred to other persons or organizations. Such organizational competence does not usually come about through explicit oncefor-all choices but through experimental learning (Eliasson 1990b). At each point in time the organization of the firm is conditioned by its organizational memory ("corporate culture") which allocates, filters, and puts people to more or less productive use within the firm. It is also constrained by physical factors, like machine capacity. Hence, the organization of a workshop in which machines are to be installed is never an optimal choice from a given menu of organizational solutions.

\subsection{Technical (Functional) Capabilities}

Technical capabilities include the firm's competence in all areas of its activity, whether defined by function (such as $\mathrm{R} \& \mathrm{D}$, engineering, production, marketing, service, finance, and general administration), or by product or market. This competence refers to the management of the current operations (i.e., controlling the physical production process and related activities) within the firm. We are now at the level of well-defined, separable activities that constitute the everyday operations of the firm.

It should be pointed out that this is the notion of the firm underlying the production function and productivity analysis in static theory. A firm with high productivity (large output with given 
inputs) or high (static) efficiency (small inputs to achieve a given output) demonstrates great functional ability. It uses the appropriate combination of inputs, has well-defined and wellexecuted routines, produces good quality output with little or no waste, etc. This type of skill reflects Schumpeter's concept of the managerial firm associated with the circular flow of goods and services in static theory where the output is given. But the essential point we want to emphasize here is that this represents only a fraction of what business activity is all about. Functional capability is necessary but not sufficient for superior economic performance; other (more dynamic) aspects of economic competence (selective, organizational, and learning) are also important.

\subsection{Learning Capabilities}

The learning capability of a firm is a form of adaptive ability: the firm's ability to learn from success as well as failure, to identify and correct mistakes, to read and interpret market signals and take appropriate actions. In order to do this, firms must be able to learn -- which means that they have to be "experimentally organized" (Eliasson 1987).

Generally, organizational learning includes the capacity to create new competence internally (through innovations) and to acquire knowledge in external markets. It also includes methods of efficiently diffusing new knowledge throughout the organization, while keeping the knowledge within the organization. Learning is a major part of the competitive process and draws significant (although not easily measured) resources.

Learning can be defined in several ways. A narrow definition is rational expectations-based "statistical" learning of the classical model (see e.g. Eliasson 1990b). Such learning does not accept tacit knowledge. A more broadly based definition is the feedback function in Figure 1, 
referring to the ability to upgrade the other three dimensions of business competence (selective, organizational, and functional), but also the adaptive dimension itself (learning how to learn better). In this view, the learning capability may be difficult to distinguish from these other types of capabilities in that it is typically conditioned by the existing (domain-specific) knowledge already possessed by the firm. ${ }^{4}$

In activities dominated by tacit, incommunicable knowledge, learning requires reallocation of people, not information. This occurs either internally or externally, via markets. From the point of view of the entire economy, such reallocation may involve entry and exit of firms. From the firm's point of view, it involves hiring, training, and reallocating people.

Malerba (1989) has pointed out that learning by firms is usually viewed by economists as a costless by-product (joint output) of production; "learning by doing" and "learning by using" focus on the "doing" and "using", not on the "learning". But such a view is much too narrow. Instead, Malerba argues, learning should be viewed as a costly and targeted process in its own right, one that takes place in all activities of the firm: production, design and engineering, $R \& D$, marketing, etc. (Malerba 1989, p. 6). Firms select, store and accumulate knowledge through learning and become endowed with different technological capabilities. Leaming by interacting with suppliers, customers and competitors is a particularly important method of obtaining information. (ibid., pp. 7-11.) One form of such interaction takes place via international activities ("the international market as a school", cf. Eliasson 1991): multinational firms "learn" in the international market by perceiving market opportunities (by identifying, interpreting, and quickly acting upon market

4 This is what Cohen and Levinthal (1990) refer to as absorptive capacity, "the ability of a firm to recognize the value of new, external information, assimilate it, and apply it to commercial ends." In our taxonomy, this is referred to as innovative or creative ability and is included in the firm's selective (strategic) capability. 
signals in various parts of the world) and by constantly monitoring a wide variety of markets, competitors, and technologies.

In the experimentally organized firm, the challenge is to reconcile operational procedures which are functioning well in a static sense (static efficiency) with the need for flexibility (dynamic efficiency) arising from creative and adaptive abilities. The firm has to constantly review its procedures and personnel, correctly estimating the limits of the competence of one's own firm (including that of top management) and that of other firms (Eliasson 1990c). Organizational learning is necessarily experimental and occurs partly as a consequence of varied careers, which reveal intellectual capacities both to the individuals involved and to their superiors. Therefore, the development of team capacity for intellectual retooling is important. The tacit nature of much of the firm's competence means that the capacity for "intellectual retooling" is often more imporiant for coping with technical change than bringing in fresh talent from outside.

\section{Measurement of Business and Economic Competence}

If one were to devise a direct measure of economic competence, it would have to be a composite measure of the various types of competence. But as already indicated, there are numerous dimensions to each type of competence. A deficiency in one dimension (say, functional) may be more than compensated for by a high degree of competence in another dimension (say, innovative ability). There are also significant unmeasurable elements: a large share of corporate capabilities represent tacit (and hence unmeasurable) knowledge; and luck (good or bad) may play an important role - although as Burton Klein has pointed out (Klein 1988) luck and necessity 
may go hand in hand, at least in dynamically efficient firms. Nevertheless, in the end it is the sum total of the firm's economic competence that matters.

For this reason, as is often the case when complex concepts are involved, it may be necessary to resort to using indirect rather than direct measures of competence, namely performance-related measures. Good performance could be defined as high (relative) profitability and increasing market share. Such proxies carry some information and may be acceptable indicators, even if they can rarely be shown to be generally valid performance measures. Thus, for instance, firms may be thought of as maximizing market share under a minimum profitability constraint, as suggested by Baumol (1959). Under certain conditions, this can be shown to be equivalent to long-term profit maximization.

Profitability, on the other hand, is a ratio. It is not always rational to maximize profitability in a bad business situation by constraining output, thereby lowering short-term profits. In the long term, the rate of return on equity is proportional to the long-term growth in asset values. Owners want to maximize the long-run value of their wealth. Therefore, the competence residing in a business firm might be said to be reflected in its capacity to generate a relatively faster growth in wealth than other firms. Under certain conditions, this ability to generate an extra rent (above the interest rate) over the long term is proportional to total factor productivity growth of the firm (Eliasson 1976, 1990b). This conclusion can readily be extended to the macro economy as the competence of all firms to generate growth in total output.

Even though we have now returned, in a sense, to where we began, we have learned something in the process. If we measure business competence indirectly through the firm's relative long-term rent generating and growth performance, we have formulated a tautological explanation. The challenge is to go beyond the tautology and explain how firms have organized 
their selection, coordination, functional, and learning activities which have generated their relative performance. This is what we are trying to do in our empirical analysis which is yet to be completed.

There are two main thrusts in our empirical analysis. One is aimed at measuring business competence and its various elements at the firm level. In the present paper we will limit ourselves to showing some examples of the type of long-term performance of firms that we are interested in analyzing. The other main thrust is to model business competence and measure its macroeconomic importance. Here we will merely summarize some early results of our efforts to model business competence in MOSES.

\section{Business Competence in Swedish Manufacturing Firms: Some Empirical Examples}

The Swedish economy has long been dominated by a small number of giant manufacturing firms. This dominance has even increased over the last few decades (Eliasson, 1991). Contrary to the trend in most other countries, the average size of manufacturing establishments has increased in Sweden in recent years (Carlsson 1989). In view of this, it is not surprising to find that the real rate of return in the largest firms has been consistently higher than in manufacturing as a whole, particularly after the mid-1970s. See Figure 2.

What is it that has caused the superior performance of these large firms? In our view, it must be attributed not so much to growth in plant and equipment as to the business competence possessed by these firms. In fact, if one calculates the investments in non-tangible assets such as research and development, marketing know-how, software, and labor training, the value of these 
"soft" (competence) assets can be shown to be of the same order of magnitude as that of tangible assets (Carlsson et al. 1981, pp. 39-46; Eliasson 1990d, pp. 80-81). If one adds to this other competence assets which we are not able to measure directly -- the ability to formulate and carry out viable strategies in international competition, to acquire, accumulate and use humanembodied competence, to design appropriate organizational structures, etc. -- i.e., large parts of business competence as defined above, it is clear that economic competence is at the core of economic performance and needs to be better understood. Its macroeconomic importance is established by the fact that over a 5 to 10 -year period, Swedish manufacturing and the Swedish economy will share the fate of these large international firms. Over a somewhat longer time perspective, the fate of the economy will depend on the ability of advancing semi-large firms to enter the stage to replace failing giants. In the very long run, newly established firms will gradually advance to important positions of macroeconomic significance.

In a previous study (Eliasson 1980, pp. 99-106), the long-term performance of four Swedish firms (Atlas Copco, L M Ericsson, MoDo, and Sandvik) was examined. Figure 3 (reproduced from that study) shows the output growth of these firms in relation to total Swedish industrial output for the period 1876-1976. While the individual patterns differ, partly reflecting differences among the industries to which these firms belong, all four firms outperformed manufacturing industry as a whole during the entire postwar period. The task in our further empirical work will be to identify the common factors and then focus on what is unique about each firm.

Similarly, the real rate of return on total capital (before taxes) in the same firms, compared to that in Swedish industry as a whole for roughly the same 100-year period, is shown in Figure 4. Here, too, the patterns vary over time and among firms. Three of the four firms have consistently outperformed Swedish industry in general during the postwar period, while MoDo 
(a forest products firm with a large share of its business in the paper and pulp industry) has generally performed worse. To what extent can the difference be explained via comparisons with other firms in the same business?

The type of analysis we have in mind here is reminiscent of that carried out in In Search of Excellence (Peters \& Waterman 1982) but aims at quantifying the various components of business competence to the extent possible and should not be limited to successful cases only.

\section{Modeling Economic Competence and Its Macroeconomic Importance}

Our modeling of economic (primarily business) competence involves the micro-based macroeconomic simulation model of the Swedish economy (MOSES). The model itself has been presented in Eliasson (1978, 1985 and 1989a), Albrecht et al. (1989), and Taymaz (1991). Two early attempts to investigate economic competence in terms of the model have been presented in Carlsson (1991) and Carlsson \& Taymaz (1991), both of which contain an overview and brief presentation of the salient features of the model. We will confine our discussion here to summarizing the main results of the analysis in the latter two papers.

Carlsson (1991) analyzes the macroeconomic effects of two particular aspects of economic competence, namely those reflected (1) in the degree of X-efficiency (Leibenstein 1966) or slack in the production process in individual firms, and (2) in differences among firms in investment behavior, resulting from their having different expectations and varying willingness and ability to finance investment by borrowing. 
It is shown that if there are important differences among firms in economic competence, the relationships between investment, productivity, and economic growth are much more complex and unpredictable than commonly assumed. The rate of technological progress as measured by the rate of change in best-practice technology seems to be less important than the elimination of inefficiency by closure of firms and/or by firms moving closer to their respective production frontiers. In other words, the distribution of investment and other features of production among plants is more important for macroeconomic performance than shifts of the frontier due to new technology, at least over a decade or two.

It is also shown that the conditions which determine firm borrowing for investment (involving their interpretation of past profitability and expectations based on current capacity utilization) are more important for productivity and economic growth than the total amount invested. In other words, it matters less how much is invested than who does the investing, and under what incentives.

The implication for productivity analysis is that unless diversity among economic units is taken into account, the results are likely to continue to be inconclusive. What is needed is much more of an integration of micro and macro theory than has been accomplished thus far. In particular, the role of economic competence must be explicitly taken into account.

Carlsson \& Taymaz (1991) broadened the analysis of economic competence to comprise three aspects, each represented in a set of simulations. The first experiment simulates what would happen if some firms were to increase their "investment efficiency," i.e. their incremental output/capital ratio. Such an increase may be the result of a variety of changes including vertical disintegration (e.g. in the form of focusing on certain core businesses while divesting non-core 
businesses), a shift to more 'downstream' investment, enhancement of efficiency and capacity utilization through elimination of bottlenecks, and generally "tighter" management.

The second experiment involves raising the level of labor productivity associated with new capital in some firms. Via more astute management, better luck in drawing from the opportunity set (perhaps as a result of higher yield on internal R\&D efforts or better utilization of innovations made by others), and similar factors, firms are in a position to take better advantage of best practice technology.

The third set of simulations focuses on the benefits of increased flexibility as represented by a reduction in the amount of time required to convert inputs into output, as well as the level of work-in-process (WIP) inventories (measured as a percentage of quarterly output).

The results show that in each case, the change has a favorable impact relative to the base case (no change), as expected. The rate of growth of output (of engineering goods, manufactured goods, as well as GNP) increases. The rate of growth of labor productivity increases, as does the average annual rate of return, particularly in comparison to the interest rate (determined endogenously in the model).

For example, the results indicate that a $50 \%$ increase over 5 years in the incremental output/capital ratio of all engineering plants leads to a $24 \%$ increase in the industry growth rate and a $29 \%$ increase in the labor productivity growth rate over 15 years, compared to the base case. A similar $50 \%$ increase for a subset of 18 plants (representing $10 \%$ of industry employment in the base year) leads to a $13 \%$ increase in the industry growth rate and a $19 \%$ increase in the labor productivity growth rate.

The overall impression one gets from these results is that changes in firm behavior, reflecting changes in their economic competence, may have the same macroeconomic impact as fairly 
substantial changes external to the firms (or to the economy), e.g. technological progress or foreign prices. At the very least, internal changes within firms may be of such importance that they cannot be ignored at the macroeconomic level.

It is a standard assumption in mainstream economic theory that costs for achieving technical improvements of the above three kinds, or other kinds, are nil. They are introduced as exogenous "free" shifts in the production frontier. An appropriate continuation of this research therefore is to endogenize as much as possible of the improvements in technical performance through modeling the process of improvements and the associated resource use. Significant parts of the empirical data needed are already available (see Eliasson 1990b, Eliasson and Braunerhjelm 1991, and Albrecht et al. 1991) and work in that direction is already in progress at IUI in the context of the micro-to-macro model. This amounts to establishing direct links between various competence inputs at the firm level, notably innovation and learning, and the resultant performance improvements, and studying the associated macro results through model simulations. 
References

Albrecht, James, 1979, "A Look at Capacity Utilization in Swedish Industry," in Sveriges Industriförbund, Indıstrikonjunkturen. Stockholm: Industriförbundets Förlag.

Albrecht, James, et al., 1989, MOSES Code. Research Report No. 36. Stockholm: IUI.

Albrecht, James, Pontus Braunerhjelm, Gunnar Eliasson, Thomas Nordrström and Erol Taymaz, MOSES Database. Stockholm: IUI.

Alchian, A.A. and H. Demsetz, 1972, "Production, Information Costs and Economic Organization," American Economic Review, 62 (3), pp. 777-795.

Arthur, Brian, 1989, "Positive Feedbacks in the Economy," Scientific American, 262 (February), pp. 92-99.

Babbage, Charles, 1835, On the Economy of Machinery and Manufactures, fourth edition. London: Charles Knight. (Reprinted by Augustus M. Kelley, New York, 1963.)

Baumol, W.J., 1959, Business Behavior, Value and Growth. New York: Macmillan.

Carlsson, Bo, Johan Örtengren, Petra Lantz, Tomas Pousette, Lars Jagrén and Fredrik Bergholm, 1981, Industrin inför 80-talet (Swedish Industry Facing the 80s). Stockholm: IUI.

Carlsson, Bo, 1989, "The Evolution of Manufacturing Technology and Its Impact on Industrial Structure: An International Study," Small Business Economics, 1 (1), pp. 21-37.

Carlsson, Bo, 1991, "Productivity Analysis: A Micro-to-Macro Perspective" in E. Deiaco, E. Hörnell \& G. Vickery (eds.), Technology and Investment-Crucial Issues for the 1990s. London: Pinter Publishers.

Carlsson, Bo and Erol Taymaz, 1991, "The Role of Technological Progress and Economic Competence in Economic Growth: A Micro-to-Macro Analysis.", Working paper, CWRU and IUI.

Chandler, Alfred D., 1962, Strategy and Structure: Chapters in the History of the American Industrial Enterprise. Cambridge, MA: The M.I.T. Press.

Chandler, Alfred D., 1977, The Visible Hand: The Managerial Revolution in American Business. Cambridge, MA: Harvard University Press.

Chandler, Alfred D., 1990, Scale and Scope: The Dynamics of Industrial Capitalism. Cambridge, MA: Harvard University Press. 
Cohen, Wesley M. and Daniel A. Levinthal, 1990, "Absorptive Capacity: A New Perspective on Learning and Innovation," Administrative Science Quarterly, 35 (March), pp. 128-152.

David, Paul A., 1985, "CLIO and the Economics of QWERTY," American Economic Review, 75 (2), pp. 332-337.

Dosi, G., D.J.Teece, and S.G. Winter, 1990, "Toward a Theory of Corporate Coherence: Preliminary Remarks," Working Paper.

Eliasson, Gunnar, 1976, Business Economic Planning, theory, practice and comparison, John Wiley \& Sons, London.

Eliasson, Gunnar, (ed.), 1978, A Micro-to-Macro Model of the Swedish Econony. IUI Conference Reports 1978:1. Stockholm: IUI.

Eliasson, Gunnar, 1980, "Företag, marknader och ekonomisk utveckling--en teori och några exemplifieringar" (Firms, Markets, and Economic Development-A Theory and some Illustrations) in Erik Dahmén and Gunnar Eliasson (eds.), Industriell utveckling $i$ Sverige (Industrial Development in Sweden). Stockholm: IUI.

Eliasson, Gunnar, 1985, The Firm and Financial Markets in the Swedish Micro-to-Macro Model - Theory, Model and Verification. Stockholm: IUI.

Eliasson, Gunnar, 1987, Technological Competition and Trade in the Experimentally Organized Economy. IUI Research Report No. 32. Stockholm: IUI.

Eliasson, Gunnar, 1989a, "Modeling the Experimentally Organized Economy," in J. Albrecht et al., MOSES Code. Stockholm: IUI.

Eliasson, Gunnar, 1989b, "The Dynamics of Supply and Economic Growth - How Industrial Knowledge Accumulation Drives a Path-Dependent Economic Process," in Bo Carlsson (ed.), Industrial Dynamics. Boston: Kluwer Academic Publishers.

Eliasson, Gunnar, 1990a, "The Firm as a Competent Team," Joumal of Economic Behavior and Organization, 13 (3), pp. 273-298.

Eliasson, Gunnar, 1990b, "Business Competence, Organizational Learning and Economic Growth", IUI Working Paper No. 264.

Eliasson, Gunnar, 1990c, "Financial Institutions in a European Market for Executive Competence" IUI working paper no. 265. To be published in Wihlborg, C., M. Fratianni and T.D. Willet (eds.), Financial Regulation and Monetary Arrangements after 1992. Amsterdam: North-Holland.

Eliasson, Gunnar, 1990d, "The Knowledge-Based Information Economy" in G. Eliasson et al., The Knowledge-Based Infornation Economy. Stockholm: IUI. 
Eliasson, Gunnar, 1991, "The International Firm: A Vehicle for Overcoming Barriers to Trade and a Global Intelligence Organization, Diffusing the Notion of a Nation," in Mattsson and Stymne (eds.), Corporate Strategies in Europe. Amsterdam: North Holland.

Eliasson, Gunnar, Harald Fries, Lars Jagrén and Lars Oxelheim, 1984, Hur styrs storföretag? En studie af invormationshantering och organisation (How Are Large Firms Managed? A Study of Information Handling and Organization). Stockholm: IUI.

Eliasson, Gunnar, Fredrik Bergholm, Eva Christina Horwitz and Lars Jagrén, 1985, De svenska storföretagen - en studie av internationaliseringens konsekvenser för den svenska ekonomin (The Swedish Large Corporations - A Study of the Consequences of Internationalization for the Swedish Economy). Stockholm: IUI.

Eliasson, Gunnar and Pontus Braunerhjelm, 1991, "The Nature and Value of Capital", IUI Working Paper, Stockholm.

Klein, Burton H., 1988, "Luck, Necessity, and Dynamic Flexibility," in Horst Hanusch (ed.), Evolutionary Economics: Applications of Schumpeter's Ideas. Cambridge: Cambridge University Press.

Leibenstein, Harvey, 1966, "Allocative Efficiency vs. 'X-Efficiency'," American Economic Review, 56 (3), pp. 392-415.

Machlup, Fritz, 1967, "Theories of the Firm: Marginalist, Behavioral, Managerial," American Economic Review, 57 (1), pp. 1-33.

Malerba, F., 1989, "Learning by Firms and Incremental Technical Change," Working Paper, Università degli Studi, Brescia.

Marshall, Alfred, 1890, Principles of Economics. London: Macmillan \& Co.

Mill, John Stuart, 1909, Principles of Political Economy, ed. by W.J. Ashley. London: Longmans, Green, and Co.

Pelikan, Pavel, 1988, "Can the Imperfect Innovation Systems of Capitalism Be Outperformed?," in G. Dosi et al. (eds.), Technical Change and Economic Theory. London: Pinter Publishers, Ltd.

Pelikan, Pavel, 1989, "Evolution, Economic Competence, and the Market for Corporate Control," Joumal of Economic Behavior and Organization, 12, 279-303.

Penrose, Edith T., 1959, The Theory of the Growth of the Firm. Oxford: Basil Blackwell.

Peters, T. and R.H. Waterman, 1982, In Search of Excellence. New York: Harper \& Row. 
Polanyi, M., 1958, Personal Knowledge: Towards a Post-Critical Philosophy. New York: Harper Torchbooks.

Polanyi, M., 1966, The Tacit Dimension. Garden City, NY: Doubleday \& Co., Inc.

Prahalad, C.K., and G. Hamel, 1990., "The Core Competence of the Corporation," Harvard Business Review, May-June, 79-91.

Romer, Paul M., 1986, "Growth Based on Increasing Returns and Long-Term Growth," Joumal of Political Econony, 94 (5), pp. 1002-1037.

Schumpeter, Joseph A., 1912, Theorie der wirtschaftlichen Entwicklung. Leipzig: Duncker \& Humblot.

Schumpeter, J.A., 1934, The Theory of Economic Development. Cambridge, MA: Harvard University Press (German edition published in 1911).

Selznick, P., 1957, Leadership in Administration. New York: Harper \& Row.

Simon, Herbert A., 1955, "A Behavioral Model of Rational Choice,' Quarterly Joumal of Economics, 69, pp. 99-118.

Simon, Herbert A., 1957, Models of Man. New York: John Wiley.

Taymaz, Erol, 1991, MOSES on PC: Manual, Initialization, Calibration. Stockholm: IUI.

Teece, David J., 1988, "Technological Change and the Nature of the Firm" in G. Dosi et al., (eds.), Technical Change and Economic Theory. London: Pinter Publishers.

Westerman, J., 1768, Om de svenske näringames undervigt gentemot de utländske dymedelst en trögare arbetsdrift (On the Inferiority of Swedish Manufacturers Compared to Foreign Ones Due to a Slower Work Organization). Stockholm.

Williamson, Oliver E., 1975, Markets and Hierarchies: Analysis and Antitrust Implications. New York: Free Press. 
Figure 1 The Competence Hierarchy of a Business Organization

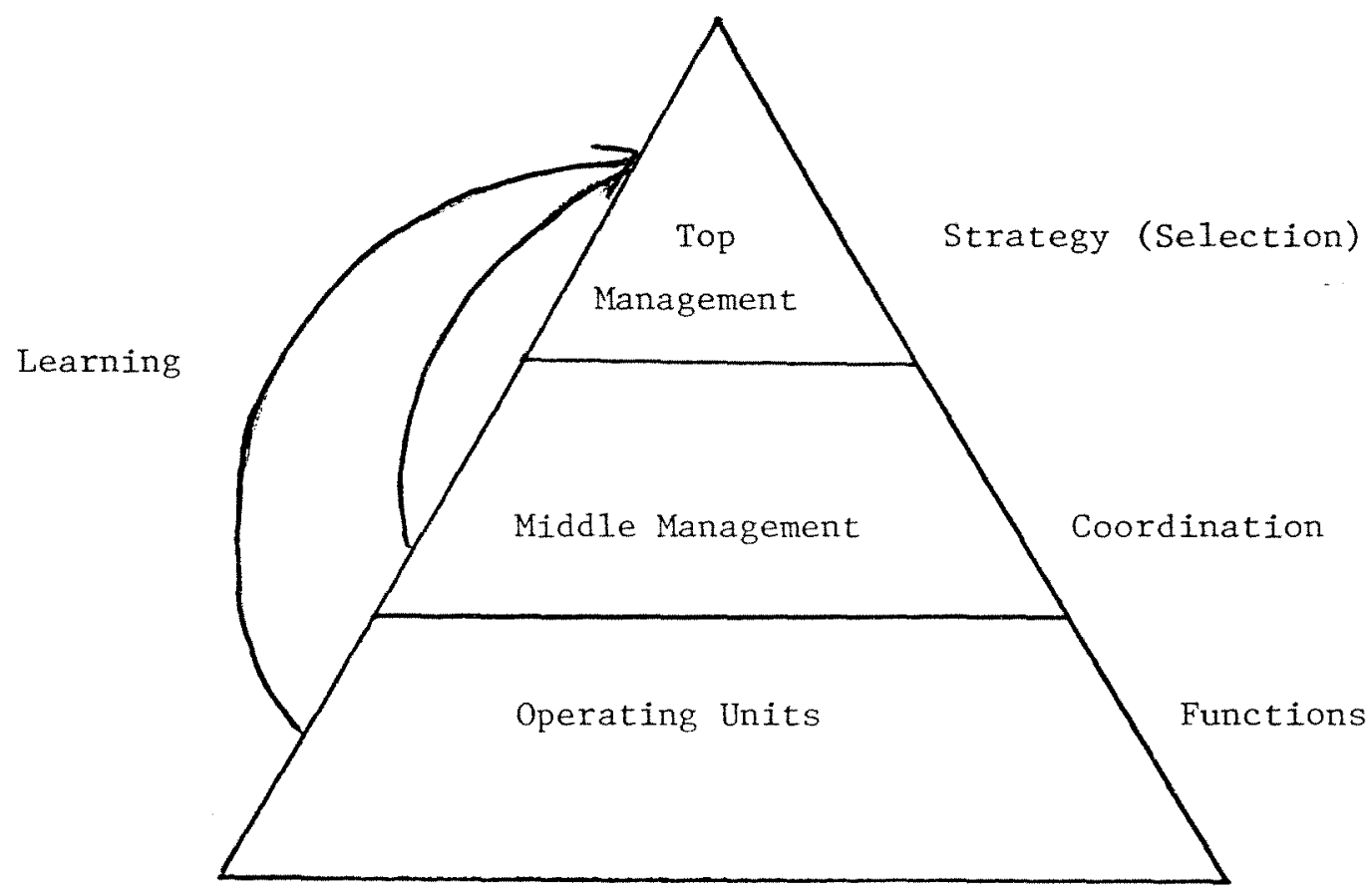


Figure 2 The real rate of return in 10 large international Swedish firms and in all domestic manufacturing

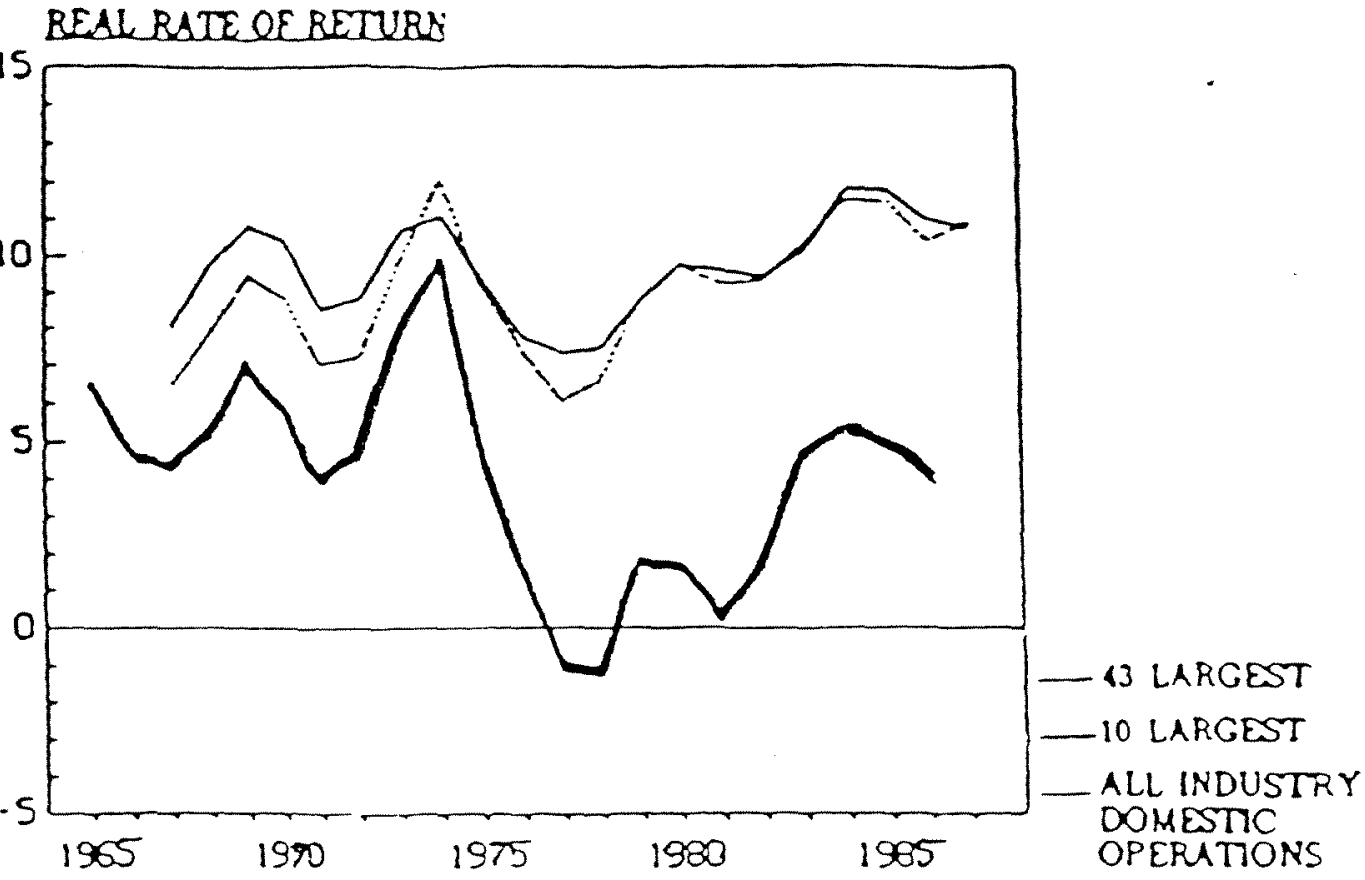

Source: Eliasson, G., 1991, "The International Firm: A Vehicle for Overcoming Barriers to Trade and a Global Intelligence Organization, Diffusing the Notion of a Nation," IUI Working Paper No. 201, Stockholm. 
Figure 3 Output Growth in Four Swedish Manufacturing Firms Relative to Total Swedish Manufacturing Industry, 18761976

$$
\text { Index, } 1876=100
$$

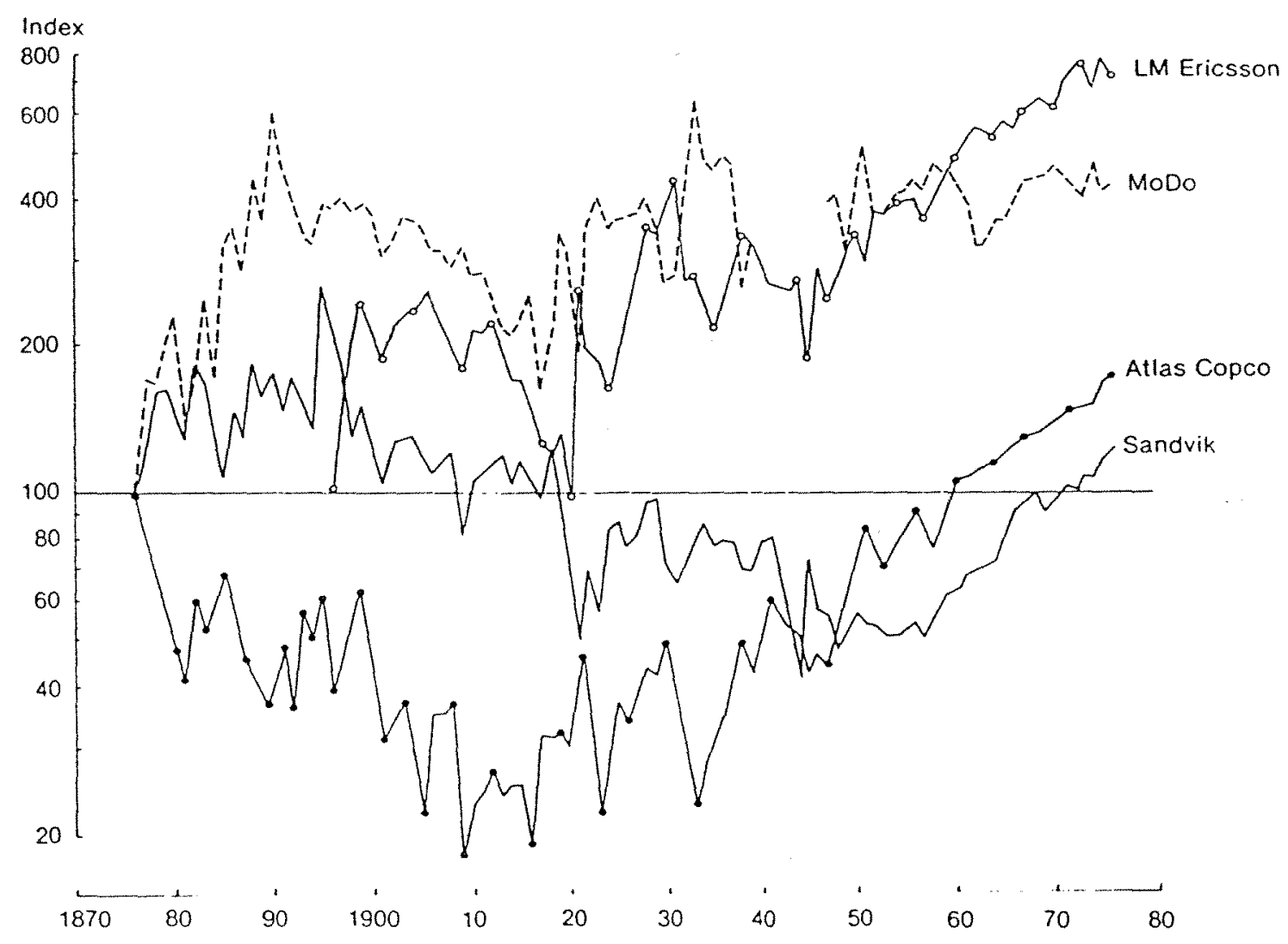


Figure 4 Real Rate of Return on Total Assets for Four Swedish Manufacturing Firms Compared with the Rate of Return in Manufacturing Industry, 1870-1970

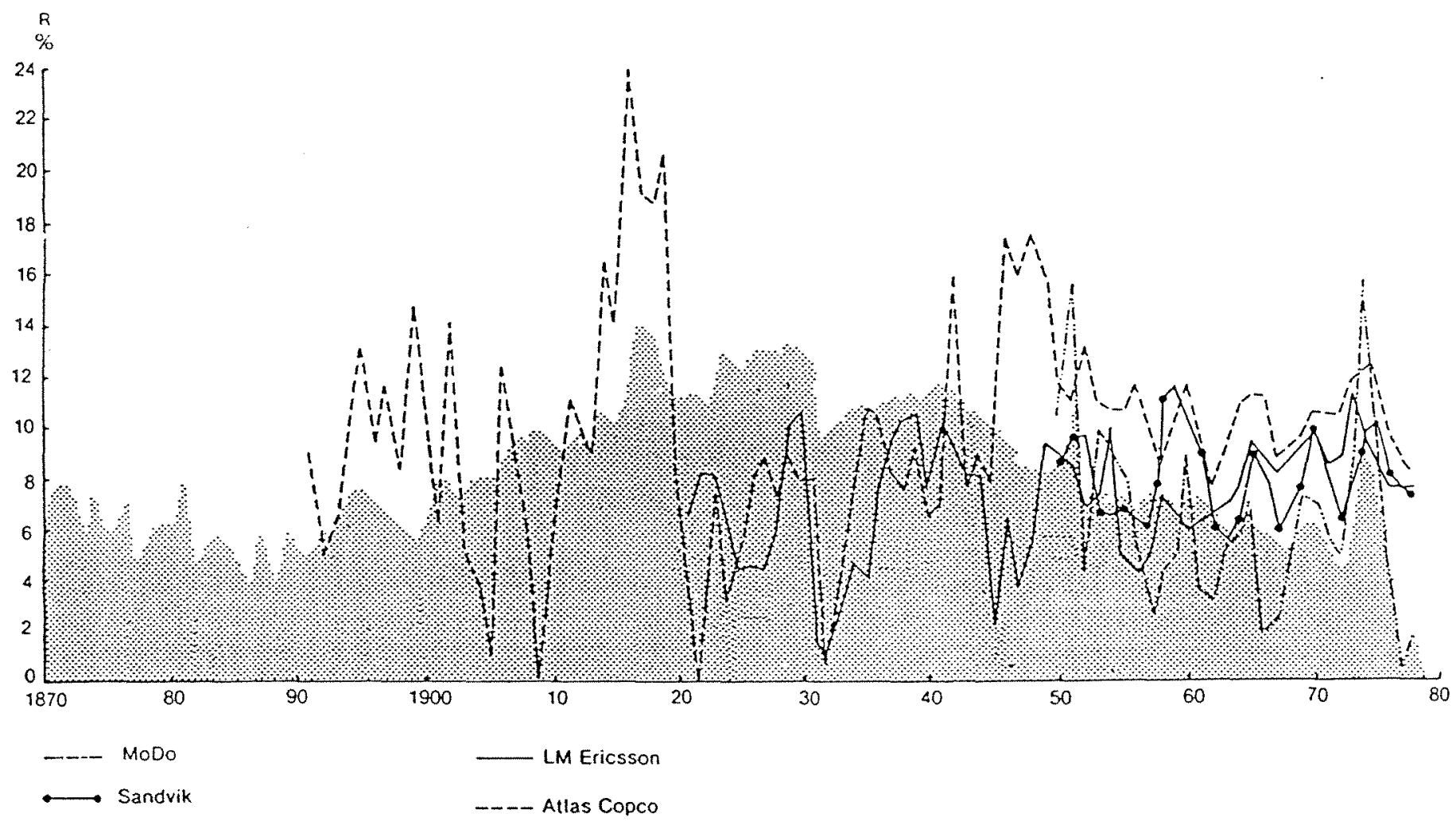

Note: The shaded area represents the rate of return in manufacturing industry as a whole. 